\title{
The use of asparaginase to reduce acrylamide levels in cooked food
}

\section{Article}

\section{Accepted Version}

Creative Commons: Attribution-Noncommercial-No Derivative Works 4.0

Xu, F., Oruna-Concha, M.-J. and Elmore, J. S. (2016) The use of asparaginase to reduce acrylamide levels in cooked food. Food Chemistry, 210. pp. 163-171. ISSN 0308-8146 doi: https://doi.org/10.1016/j.foodchem.2016.04.105 Available at https://centaur.reading.ac.uk/64518/

It is advisable to refer to the publisher's version if you intend to cite from the work. See Guidance on citing.

To link to this article DOI: http://dx.doi.org/10.1016/j.foodchem.2016.04.105

Publisher: Elsevier

All outputs in CentAUR are protected by Intellectual Property Rights law, including copyright law. Copyright and IPR is retained by the creators or other copyright holders. Terms and conditions for use of this material are defined in the End User Agreement.

\section{www.reading.ac.uk/centaur}

\section{CentAUR}

Central Archive at the University of Reading

Reading's research outputs online 
6 E-mail addresses:

$7 \quad$ Mr Fei Xu: f.xu@pgr.reading.ac.uk

8 Dr Maria-Jose Oruna-Concha; M.J.Oruna-Concha@,reading.ac.uk

9

10

\section{RESEARCH HIGHLIGHTS} reaction. colour.
Fei Xu, Maria-Jose Oruna-Concha, J. Stephen Elmore*

Department of Food and Nutritional Sciences, University of Reading, Whiteknights, Reading RG6 6AP, UK

Dr Stephen Elmore j.s.elmore@reading.ac.uk (*corresponding author; tel.: +118-3787455)

Strategies to reduce acrylamide in cooked food often rely on a reduction in the Maillard

Mitigation procedures that modify the Maillard reaction may negatively affect flavour and

Asparaginase may reduce acrylamide formation, while maintaining sensory quality. This review collates research on the use of enzymes to mitigate acrylamide formation. 
ABSTRACT

27

Strategies proposed for reducing the formation of the suspected carcinogen acrylamide in cooked foods often rely on a reduction in the extent of the Maillard reaction, in which acrylamide is formed from the reaction between asparagine and reducing sugars. However, the Maillard reaction also provides desirable sensory attributes of cooked foods. Mitigation procedures that modify the Maillard reaction may negatively affect flavour and colour. The use of asparaginase to convert asparagine to aspartic acid may provide a means to reduce acrylamide formation, while maintaining sensory quality. This review collates research on the use of enzymes, asparaginase in particular, to mitigate acrylamide formation. Asparaginase is a powerful tool for the food industry and it is likely that its use will increase. However, the potential adverse effects of asparaginase treatment on sensory properties of cooked foods and the need to achieve sufficient enzyme-substrate contact remain areas for future research.

Key words: Acrylamide, asparaginase, enzymes, asparagine, reducing sugars, Maillard reaction 


\section{Introduction}

It is now over ten years since the Swedish Food Authority and the University of Stockholm confirmed the existence of the suspected carcinogen acrylamide in a variety of heated foods (Tareke, Rydberg, Karlsson, Eriksson, \& Tornqvist, 2002). Several months after the announcement, researchers showed that acrylamide is formed from asparagine and reducing sugars during the Maillard reaction (Mottram, Wedzicha, \& Dodson, 2002; Stadler et al., 2002). As shown in Figure 1, asparagine and reducing sugars take part in a conjugation reaction resulting in the formation of $\mathrm{N}$-glycosylasparagine, which as a result of high temperature treatment will form a decarboxylated Schiff base. The decarboxylated Schiff base may decompose directly to form acrylamide or may hydrolyse to form 3aminopropionamide (Hedegaard, Frandsen, \& Skibsted, 2008). 3-Aminopropionamide is also believed to be an important precursor of acrylamide (Granvogl \& Schieberle, 2006).

Since 2002, the food industry worldwide has collaborated with scientists, in order to reduce the levels of acrylamide in cooked foods. Mitigation techniques can be separated into three different types. Firstly, starting materials low in acrylamide precursors can be used to reduce the acrylamide in the final product. Secondly, process conditions may be modified, in order to decrease the amount of acrylamide formation. Thirdly, post-process intervention could be used to reduce acrylamide (Pedreschi, Mariotti, \& Granby, 2014). While the third approach is not widely considered, an example is the use of supercritical $\mathrm{CO}_{2}$ extraction to reduce acrylamide levels in coffee. Almost $80 \%$ of the acrylamide was removed using this technique (Banchero, Pellegrino, \& Manna, 2013), although further sensory tests are needed to validate the effect on food quality.

This review will describe the main mitigation strategies used for acrylamide but will focus on the use of enzymes, in particular asparaginase, to reduce levels of acrylamide precursors. A more general review on acrylamide mitigation has been recently published (Friedman, 
2015), while another recent review has covered the latest studies on the sources, purification, and characterisation of L-asparaginase and its application in both the pharmaceutical and food industries (Zuo, Zhang, Jiang, \& Mu, 2015a).

\section{Acrylamide mitigation strategies}

\subsection{Raw materials}

Decreasing the amounts of acrylamide precursors will have a huge impact on final acrylamide production (Zyzak et al., 2003). However, the effect will be dependent on the relative levels of precursors. If total reducing sugars are present at higher levels than asparagine in a food, reduction in asparagine will have the greater effect on acrylamide formation, and vice versa. Numerous papers have demonstrated that acrylamide formation is proportional to reducing sugar concentrations in potato (Elmore, Briddon, Dodson, Muttucumaru, Halford, \& Mottram, 2015; Ohara-Takada et al., 2005; Vinci, Mestdagh, \& De Meulenaer, 2012), while in cereals, such as rye and wheat, acrylamide formation is proportional to asparagine content (Curtis et al., 2010; Halford, Curtis, Muttucumaru, Postles, Elmore, \& Mottram, 2012). Hence potato varieties low in reducing sugars and cereal varieties low in asparagine are sought. Storage may increase levels of reducing sugars in stored potatoes, particularly under low-temperature conditions (Rak, Navarro, \& Palta, 2013), while levels of fertilisation, for example nitrogen and sulfur, may have effects on reducing sugars and asparagine levels in both potatoes and cereals (Elmore, Mottram, Muttucumaru, Dodson, Parry, \& Halford, 2007; Muttucumaru et al., 2006; Muttucumaru, Powers, Elmore, Mottram, \& Halford, 2013). It is clear, however, that little or no acrylamide will form in the absence of asparagine, while other components of the food matrix, such as lipid-derived aldehydes (Zamora \& Hidalgo, 2008), amino acids such as serine and threonine (Shu, 1999), and other 
carbonyl-containing molecules (Hamzalioğlu \& Gökmen, 2012; Zamora, Delgado, \&

Hidalgo, 2011), can react with asparagine to form acrylamide.

\subsection{Process-based mitigation}

Initial mitigation methods involved the control of processing conditions; for instance, lowering $\mathrm{pH}$, reducing cooking temperature and shortening the processing time (Palazoğlu \& Gökmen, 2008). Although these methods achieved an effective reduction of acrylamide, sensory properties of the food were compromised. As the Maillard reaction begins when food is heated, the first option in this type of mitigation method is to lower the temperature and time of heating. However, as the Maillard reaction is also responsible for generating desirable taste and smell in cooked food, sensory properties become unacceptable when cooking temperature is substantially reduced (Masi, Dinnella, Barnaba, Navarini, \& Monteleone, 2013).

Besides temperature, another important parameter, $\mathrm{pH}$, has also been studied. In a model system, the acrylamide content will reach a maximum amount when the $\mathrm{pH}$ is around 8 , which is near to the $\mathrm{p} K_{\mathrm{a}}$ value of asparagine and leads to an enhancement in the initial steps of acrylamide formation (Rydberg, Eriksson, Tareke, Karlsson, Ehrenberg, \& Tornqvist, 2003). Several authors have reduced acrylamide formation by reducing the $\mathrm{pH}$, using compounds such as citric acid (Gama-Baumgartner, Grob, \& Biedermann, 2004), although product quality has suffered generally using this approach (Vinci, Mestdagh, \& De Meulenaer, 2012).

\subsection{Use of additives}

Adding other chemicals prior to or after heating could also decrease the final acrylamide amount in a cooked product. For example, adding glycine before heating will compete with asparagine to lower the final acrylamide amount (Bråthen \& Knutsen, 2005). It could also be 
added after the Maillard reaction, to react with acrylamide directly, thus lowering its amount in the final product (Liu, Man, Zhu, Hu, \& Chen, 2013). However, this method also has negative effects on the sensory properties of the product, as added glycine will react with reducing sugars to increase levels of odour-active alkylpyrazines (Low, Parker, \& Mottram, 2007)

The addition of divalent cations has also been shown to be an effective means of reducing acrylamide. Nixtamalisation, the traditional cooking of corn grains in calcium hydroxide solution prior to milling, is traditionally used in the preparation of tortillas (Salazar, Arambula-Villa, Luna-Barcenas, Figueroa-Cardenas, Azuara, \& Vazquez-Landaverde, 2014).

A calcium chloride dip for potatoes reduced acrylamide in French fries by $95 \%$, with no adverse effects on product quality reported. The effect is due to the divalent cations inhibiting formation of the Schiff base (Gökmen \& Șenyuva, 2007). Monovalent cations at low concentrations may also exhibit a mitigation effect. Addition of $1-2 \%$ sodium chloride to a bread mix led to a substantial reduction in acrylamide in baked rolls. Higher salt concentrations inhibited yeast growth, resulting in increased acrylamide formation (Claus, Mongili, Weisz, Schieber, \& Carle, 2008). A 2\% sodium chloride dip pre-treatment (60 min, room temperature) resulted in a $78 \%$ reduction in acrylamide in fried potato discs (Sansano, Juan-Borras, Escriche, Andres, \& Heredia 2015).

Antioxidants could also be added to inhibit the formation of acrylamide. However, effects were variable in the several studies carried out during the past decade, due to the various types of antioxidants used (Jin, Wu, \& Zhang, 2013). For instance, rosemary added to corn or olive oil could effectively lower the amount of acrylamide in fried potato slices (Becalski, Lau, Lewis, \& Seaman, 2002), while some commonly used antioxidants, such as BHT, sesamol and Vitamin E, had an enhanced effect on acrylamide formation in cooked meat (Tareke, 2003). The reducing or promoting effects could be attributed to differences in 
reaction conditions, antioxidant dosage and different reaction pathways.

\subsection{Enzymatic approaches for acrylamide reduction}

Fermentation methods use specific microorganisms to consume the asparagine or reducing sugar before the food processing step (Sadd, Hamlet, \& Liang, 2008). For instance, a starter medium containing lactic acid bacteria was used in the preparation of wholemeal rye bread and substantially reduced acrylamide levels in the final product (Bartkiene, Jakobsone, Juodeikiene, Vidmantiene, Pugajeva, \& Bartkevics, 2013b). As well as lowering the pH, the lactic acid bacteria reduced the levels of reducing sugars in the dough.

However, there are several points that need to be considered in a fermentation approach. To begin with, the temperature and $\mathrm{pH}$ need to be controlled in order to maximise the activity of the microorganism. Even if the reducing sugar consumed was added back after processing, the sensory quality of the final product may still be affected by the fermentation step (Bartkiene, Jakobsone, Juodeikiene, Vidmantiene, Pugajeva, \& Bartkevics, 2013a). Secondly, fermentation predominantly works in bakery products, with limited application application in potato-based products and coffee (Kamkar, Qajarbeygi, Jannat, Babaei, Misaghi, \& Aghaee, 2015).

The use of an enzymatic approach to modify reaction pathways was first proposed by Amrein et al. (2004), who used asparaginase to hydrolyse asparagine to aspartic acid and ammonia (Ciesarová, Kiss, \& Boegl, 2006). This approach is considered to be effective because asparagine is not considered a major contributor to the overall flavour and colour of cooked foods (Parker, Balagiannis, Higley, Smith, Wedzicha, \& Mottram, 2012), so desirable sensory properties are maintained. 


\section{Asparaginase}

Asparaginase (L-asparagine amidohydrolases EC 3.5.1.1) is an enzyme widely distributed in animals, plants and living organisms (Wriston, 1985). It has been shown that asparaginase catalyses the hydrolysis of asparagine into aspartic acid and ammonia by hydrolysing the amide group in the side chain of asparagine (Hendriksen, Kornbrust, Ostergaard, \& Stringer, 2009). Aspartic acid will then enter the citric acid cycle, playing a vital role in amino acid metabolism. Asparagine is responsible for nitrogen storage in most plants; therefore, asparaginase plays an important role in energy utilisation (Sieciechowicz, Joy, \& Ireland, 1988).

L-Asparaginase has been used as a therapeutic treatment for certain kinds of cancer, such as leukaemia (Bushman, Palmieri, Whinna, \& Church, 2000). In leukaemia sufferers malignant cells depend more on exogenous asparagine and glutamine to survive than normal cells. Asparaginase injected into the bloodstream hydrolyses free asparagine into aspartic acid and ammonia, and glutamine to glutamic acid and ammonia (Friedman, 2003). In this way, the growth of malignant cells is inhibited.

L-Asparaginase is an intracellular enzyme which is obtained from a variety of microorganisms: Escherichia coli, Erwinia carotovora, Bacillus sp., Enterobacter aerogenes, Corynebacterium glutamicum, Pseudomonas stutzeri and Candida utilis (Qin \& Zhao, 2003). For pharmaceutical uses, L-asparaginase is typically obtained from Escherichia coli (Pritsa \& Kyriakidis, 2001). However, the production of the enzyme is complex with low yield. Until now, there is no medium that has been specifically established for the optimum production of L-asparaginase from different microorganisms. To maximise enzyme production, each organism has its own optimum conditions. Research on E. coli using response surface methodology achieved a 10-fold enhancement in asparaginase production (Kenari, Alemzadeh, \& Maghsodi, 2011). 
Most asparaginases are quite specific for asparagine. Optimal activity is usually achieved

at $\mathrm{pH} \mathrm{5-7}$ and $37^{\circ} \mathrm{C}$. However, as glutamine has similar structure to asparagine, some enzymes also have a low activity towards glutamine (Krasotkina, Borisova, Gervaziev, \& Sokolov, 2004). A small group of enzymes, called glutaminase-asparaginases, have activities for both asparagine and glutamine but prefer glutamine as a substrate (Roberts, Holcenberg, \& Dolowy, 1972). Crystallographic study has shown that both types of asparaginase, common asparaginase and glutaminase-asparaginase, have the same basic structure and catalytic mechanism but differ in working conditions ( $\mathrm{pH}$ and temperature) (Yao, Yasutake, Morita, \& Tanaka, 2005). Researchers believe that glutaminase activity caused by glutaminase-asparaginase will exert serious adverse effects on human health, such as liver dysfunction, pancreatitis and leucopoenia (Mahajan, Saran, Kameswaran, Kumar, \& Saxena, 2012). Therefore, this specific type of asparaginase should be strictly avoided in the food industry.

Commercially, there are two asparaginase products currently available for acrylamide mitigation in the food industry. These are PreventASe ${ }^{\mathrm{TM}}$ from DSM (Heerlen, The Netherlands) and Acrylaway ${ }^{\circledR}$ from Novozymes A/S (Bagsvaerd, Denmark). PreventASe ${ }^{\mathrm{TM}}$ was the first, launched in 2007. It was obtained after analysing the gene sequence of Aspergillus niger and produced recombinant in the Aspergillus niger host. It has an acidic profile (optimum $\mathrm{pH} 4-5$, temperature $50{ }^{\circ} \mathrm{C}$ ). Acrylaway ${ }^{\circledR}$ on the other hand, is obtained from Aspergillus oryzae and has an almost neutral profile (optimum $\mathrm{pH}$ 7, temperature 37 $\left.{ }^{\circ} \mathrm{C}\right)$.

Regarding safety, these enzymes are produced by specific fungal strains of A. oryzae and A. niger, fungi that have been widely used in commercial products for several decades and have been proved to be safe by JECFA (JECFA, 2007). Acrylaway ${ }^{\circledR}$ and PreventASe ${ }^{\mathrm{TM}}$ have shown high specificity and therefore minimum activity towards glutamine and other amino 
acids. Ultimately, these enzymes will be deactivated during the heating process, ensuring their safe application in foodstuffs (Hendriksen et al., 2009).

Asparaginase has received "generally recognized as safe" status from the US government. It has also been given a favourable evaluation as a food additive by the Joint FAO/WHO Expert committee (JEFCA, 2007) and it is currently used in several countries, including United States, Australia, New Zealand, China, Russia, Mexico and several European countries. As different dosages of asparaginase will be used in different types of food, there is no unified standard for the maximum dosage.

\subsection{Use of asparaginase in acrylamide mitigation}

As shown in Table 1, over the last decade there have been numerous studies monitoring the reduction of acrylamide formation by means of asparaginase treatment. The first study was carried out by Zyzak et al. in 2003, immediately after the formation mechanism was revealed. However, Zyzak's research was focused on the formation mechanism rather than the mitigation efficiency. He used commercial asparaginase from Aldrich (A2925 from Erwinia chrysanthemi), $50 \mathrm{U}$ added to $60 \mathrm{~g}$ of mashed potato slurry (15 g potato, $45 \mathrm{~g}$ water), to hydrolyse the asparagine, in order to verify that asparagine is indeed the precursor of acrylamide. The asparaginase achieved an $88 \%$ asparagine reduction that led to $99 \%$ acrylamide reduction in a microwaved mashed potato snack, heated at full power until brown (Zyzak et al., 2003).

The following year, the first paper on the use of asparaginase as an acrylamide mitigation method was published. Asparaginase (from E. coli, $4 \mathrm{U} / \mathrm{kg}$ ) added to gingerbread hydrolysed approximately $75 \%$ of the free asparagine, leading to a 55\% acrylamide reduction in the final product. The acrylamide-reduced product was identical to a control product in both colour and taste (Amrein, Schönbächler, Escher, \& Amadò, 2004). Though this enzyme application 
formed only a small part of the research, it stressed the advantage of the enzymatic method on mitigating acrylamide while maintaining the organoleptic properties of the product.

Ciesarová et al. (2006) set up a model system to examine the importance of all the related factors, such as temperature, dosage and application time. However, there were insufficient time and temperature points studied to determine optimum activity. Applying asparaginase to dried potato powder led to a $90 \%$ acrylamide reduction in cooked product. However, instead of considering the effect of the cut and shape of the potato products, this research focused more on potato varieties. Although this research showed great success in acrylamide reduction, the agronomic factors were discussed more than the enzyme itself.

Pedreschi, Kaack, and Granby (2008) were the first to publish results using a commercial asparaginase (Acrylaway ${ }^{\circledR}$ ). They established that the optimum temperature and $\mathrm{pH}$ for this enzyme were $60{ }^{\circ} \mathrm{C}$ and 7.0, respectively. A reduction of $67 \%$ in acrylamide was achieved in French fries under these conditions. In this study, the importance of blanching and temperature control of asparaginase treatment was highlighted. It is known that blanching will change the microstructure of the potato strips and increase the contact probability of asparaginase and asparagine (Lisińska, Tajner-Czopek, \& Kalum, 2007), so blanching is highly recommended for increasing the performance of the enzyme.

Another study by the same group focused on the combination of asparaginase (Acrylaway®) and conventional blanching, alongside their individual usage. Blanching using hot water at $85^{\circ} \mathrm{C}$ to treat the potato tuber samples for 3.5 min was compared with enzymatic mitigation using an asparaginase solution (10000 ASNU/L) at $50{ }^{\circ} \mathrm{C}$ for $20 \mathrm{~min}$. One ASNU is defined as the amount of asparaginase that produces one micromole of ammonia per minute under standard conditions ( $\mathrm{pH} 7 ; 37^{\circ} \mathrm{C}$ ). Experimental results showed that blanching and enzyme treatments have a similar effect on acrylamide reduction (17\%). By combining the two methods, almost $90 \%$ of acrylamide was mitigated. The authors assumed that the 
microstructure of the potato tissues was changed in the blanching process, causing the asparagine in the cell to have a more effective interaction with the enzyme outside the cell (Pedreschi, Mariotti, Granby, \& Risum, 2011). Although acrylamide in this research was significantly reduced, no sensory analysis of the product was performed.

In 2009, another study involving Acrylaway® was carried out on a much wider range of foods, including gingerbread, crispbread, semi-sweet biscuits, French fries and crisps (Hendriksen et al., 2009). Again the optimum conditions of temperature and $\mathrm{pH}$ were $60{ }^{\circ} \mathrm{C}$ and 7.0. In this study, other factors were also taken into consideration, depending on the food matrix. In semi-sweet biscuits, the dosage was the variable and the temperature was set at 40 ${ }^{\circ} \mathrm{C}$. Asparaginase treatment took place at the dough resting time before the biscuits were baked at $260{ }^{\circ} \mathrm{C}$ for $5.5 \mathrm{~min}$ (Fig. 2a). For the crispbread trial, the temperature was held at 10, 15 ,or $20{ }^{\circ} \mathrm{C}$ for 30 or $60 \mathrm{~min}$ and the dosage was set at 2100 ASNU/kg of flour. Then the crispbread was baked at $250{ }^{\circ} \mathrm{C}$ for $11 \mathrm{~min}$ (Fig. 2b). By changing the dosage of enzyme and time, the influences of each factor are revealed. Besides dosage and temperature, water content is another important factor in a cereal-based product like gingerbread, as higher water activity will provide sufficient contact for the enzyme with the substrate. Therefore, in order not to compromise final product sensory quality, a higher water content is recommended, although a further drying step may be needed subsequently. For potato-based products, a reduction was achieved in both French fries and crisps. Potatoes made into French fries were treated with $10500 \mathrm{ASNU} / \mathrm{L}$ and then fried for $3 \mathrm{~min}$ at $175^{\circ} \mathrm{C}$. Sliced potatoes used to make potato crisps were treated with various concentrations of enzyme for $15 \mathrm{~min}$ at $40{ }^{\circ} \mathrm{C}$. Then frying was conducted for $2.5 \mathrm{~min}$ at $180{ }^{\circ} \mathrm{C}$. In the French fries experiment, the authors prepared a sample set with a one-minute dip and 20 minutes soaking in the enzyme bath. Although the acrylamide reduction in the one-minute dip (59\% maximum) was less than for the samples in the 20-min soak ( $85 \%$ maximum), the results were still meaningful for the 
practical continuous process. Results indicated a broad range of enzyme applications. The authors suggested that by combining modified processing conditions with an enzymatic approach, acrylamide could be mitigated at a fairly low cost. The key point in this research is that the authors tried to assess all related variables and generate specific solutions for each type of product from an enormous data-set.

Also in 2009, Kukurová, Morales, Bednáriková, and Ciesarová (2009) used two levels of Acrylaway ${ }^{\circledR}(100 \mathrm{U} / \mathrm{kg}$ and $500 \mathrm{U} / \mathrm{kg}$ flour $)$ in the preparation of fried bread rolls. The asparaginase treatment $\left(15 \mathrm{~min}, 37^{\circ} \mathrm{C}\right)$ removed at least $96 \%$ of the asparagine from the dough; acrylamide could not be quantified in the fried rolls with Acrylaway® added, while levels of $215 \mu \mathrm{g}$ per $\mathrm{kg}$ were present in control rolls fried at $200{ }^{\circ} \mathrm{C}$ for $8 \mathrm{~min}$. The same group also studied acrylamide formation in cookies treated with Acrylaway® (500 U/kg flour) and different raising agents (Kukurová, Ciesarová, Mogol, Açar, \& Gökmen, 2013). The raising agents increased the $\mathrm{pH}$ of the dough, reducing the effectiveness of the asparaginase in reducing asparagine. When applied for less than 30 minutes, the asparagine had no effect on the sensory properties of the cookies.

Hendriksen, Budolfsen, and Baumann (2013) used Acrylaway ${ }^{\circledR}$ to study potato and cereal products and also carried out the first experiments on the effect of asparaginase on acrylamide in coffee. For cereal products, the mitigation efficiency reached $95 \%$ in lebkuchen and $90 \%$ in tortilla chips, whereas in coffee a $70-80 \%$ reduction was achieved. In potato products, experiments on potato tuber snack pellets and French fries were carried out. In potato tuber snack pellets, the enzyme was added directly to a dough based on $29 \%$ potato starch, $27.6 \%$ potato granules, $15 \%$ potato flakes, $1.4 \%$ salt and $27 \%$ water, while in the French fries test, Bintje or Maris Piper potatoes were manually peeled and cut into $8 \mathrm{~mm} \times 8$ mm strips. Two innovative points of this study stands out. First, asparaginase is added at the disodium acid pyrophosphate (SAPP) dipping stage rather than as a separate step. SAPP is 
commonly used in potato processing to prevent after-cooking darkening. Integrating the two treatments could reduce time and cost. Secondly, an industrial scale trial was carried out to test the mitigation efficiency of asparaginase in continuous processing. Such trials will push the industrial application of asparaginase forward. Reductions in potato product were comparatively low, due to the insufficient contact of asparagine and enzyme. However, the industrial scale experiment ( 8 tonne/h) still achieved satisfactory results; a $43 \%$ reduction in $10 \mathrm{~mm} \times 10 \mathrm{~mm}$ and $53 \%$ reduction in $7 \mathrm{~mm} \times 7 \mathrm{~mm}$ potato pieces was achieved. A dyebased experiment indicated that asparaginase could only penetrate $1 \mathrm{~mm}$ into the potato, again highlighting the importance of incorporating a blanching step when treating potatoes (Hendriksen et al., 2013).

For coffee, increased acrylamide mitigation could be achieved by incubating the wetted green beans. Typically, green coffee beans are steamed to decrease the caffeine content. The decaffeination process is usually carried out by a water or solvent partition system. Firstly, green coffee beans are steamed to make the caffeine available. Then, a solvent is used to extract the caffeine. Finally, the green beans are steamed again to remove any residual solvent (Spiller, 1997). Hence, asparaginase could be infused during these steps with minor changes to the processing conditions. A laboratory-scale experiment indicated that a low dosage (2000-6000 ASNU) of asparaginase could achieve 55-74\% acrylamide reduction in coffee beans (Hendriksen et al., 2013), while work in our laboratory showed that both the steaming step and the asparaginase treatment caused a reduction in free asparagine when the coffee was roasted, which was reflected in acrylamide losses from $69 \%$ to $86 \%$ using dosages of 2600 to 20000 ASNU, respectively (Xu, Khalid, Oruna-Concha, \& Elmore, 2015).

The effect of asparaginase on acrylamide mitigation in biscuits has also been examined by Anese, Quarta, and Frias (2011). The authors used asparaginase levels from 100 to 900 ASNU (Acrylaway ${ }^{\circledR}$ ) with $20-54{ }^{\circ} \mathrm{C}$ incubation temperature and $10-30$ min incubation time, 
15 treatments in all. By analysing the results from each treatment, the influence of each factor was considered and optimum conditions could be obtained. This study not only demonstrated a method that could assess the effect of the enzyme but compared the effect obtained with the cost for each treatment. This paper also contained valuable advice on the practical application of asparaginase. For instance, acrylamide development was at a minimum at intermediate asparaginase concentrations and increased asparaginase addition did not significantly affect the colour of the final product.

We are only aware of one publication where PreventASe ${ }^{\mathrm{TM}}$ was used as the asparaginase source. A solution of $500 \mathrm{ASNU}$ in $10 \mathrm{~mL}$ of water was spread onto the surface of a wheat/oat bread loaf prior to baking. The enzyme was effective during a proofing step of 15 min at $32{ }^{\circ} \mathrm{C}$. This treatment led to a $46 \%$ reduction in the acrylamide content of the baked bread crust (Ciesarová et al., 2014).

\subsection{New sources of asparaginase}

Recent papers have identified new sources of asparaginase for acrylamide reduction. Tuncel, Y1lmaz, and Șener (2010) used asparaginase from a vegetable source. They germinated pea flour to enhance asparaginase activity and remove beany flavour. The pea flour was finely ground and then added to wheat flour in white wheat bread, wheat bran bread and wholegrain white bread at three different levels (1\%, 3\% and 5\%). The bread was baked at $220{ }^{\circ} \mathrm{C}$ for $22-25 \mathrm{~min}$. In white wheat bread acrylamide reduction was less than $10 \%$ in all cases, while addition of 5\% pea flour to bran bread and grain bread reduced acrylamide levels in crust by $57 \%$ and $68 \%$, respectively. Although the sensory panel showed detectable differences in the final products, there was no significant negative impact on sensory properties. The extraction of asparaginase from fungus is relatively costly; therefore this approach provides an effective alternative means to produce asparaginase. 

licheniformis and was used to reduce acrylamide in fried potato strips by up to $80 \%$ (Mahajan, Saran, Kameswaran, Kumar, \& Saxena, 2012).

Asparaginase produced from Cladosporium sp. was used in the crumb and crust of sweet bread (Kumar, Shimray, Indrani, \& Manonmani, 2014). The dosage used varied from 50-300

U. However, the units were not defined. Reductions of $97 \%$ and $73 \%$ were achieved at $300 \mathrm{U}$ in bread crust and crumb, respectively. The authors also measured the formation of 5(hydroxymethyl)furfural, which is another potential toxicant formed in the Maillard reaction, and it was also decreased. This research also showed a new possible source for asparaginase, although yield data were not disclosed.

Asparaginase has also been extracted from Rhizomucor miehei (Huang, Liu, Sun, Yan, \& Jiang, 2014). The extracted asparaginase, designated as RmAsnase, was optimally active at $\mathrm{pH} 7.0$ and $45{ }^{\circ} \mathrm{C}$ and was stable at this temperature for $30 \mathrm{~min}$. RmAsnase was cloned and expressed in Escherichia coli and proved highly specific towards asparagine. The researchers demonstrated that a low concentration of asparaginase $(0.5 \mathrm{U} / \mathrm{g}$ flour $)$ had much better mitigation efficiency in bread (40\%) than biscuits (15\%). However, an $80 \%$ reduction was achieved in both products at $10 \mathrm{U} / \mathrm{g}$ flour. Overall, this new enzyme showed remarkable potential both as an acrylamide mitigator and also in leukaemia therapy.

Asparaginase from food-grade Bacillus subtilis was applied to potato chips (Onishi, Prihanto, Yano, Takagi, Umekawa, \& Wakayama, 2015). Compared to a control sample, 40 $\mathrm{U}$ of asparaginase led to $80 \%$ reduction in acrylamide. One unit of the enzyme was defined as the amount that catalysed the formation of $1 \mu \mathrm{mol}$ ammonia per min; additional details were not provided by the authors. They suggested that BAsnase, as the enzyme was christened, could be used to spray potatoes prior to cooking at home. Similar reductions in acrylamide in French fries were also obtained using an asparaginase from Thermococcus zilligii. The 
purified enzyme displayed a maximum activity at $\mathrm{pH} 8.5$ and $90{ }^{\circ} \mathrm{C}$ (Zuo, Zhang, Jiang, \& $\mathrm{Mu}, 2015 \mathrm{~b}$ ) and retained $70 \%$ of its original activity after 2 hours incubation at $85{ }^{\circ} \mathrm{C}$. Another asparaginase with high temperature stability was recently isolated from Pyrococcus furiosus (Kundu, Bansal, \& Mishra, 2013). In addition, at the end of 2013 Novozymes processing (http://www.novozymes.com/en/news/news-archive/Pages/New-Novozymes'solution-enables-acrylamide-mitigation-in-even-more-product-categories--.aspx.) Enzymes stable at such temperatures can be incorporated into the blanching step of a commercial process, which would increase their applicability.

Immobilised asparaginase may not convert as much asparagine as free asparaginase but its stability is improved, meaning that blanching water containing immobilised enzyme can be re-used several times without loss of asparaginase activity. The asparaginase is immobilised by crosslinking with glutaraldehyde on an inert silica-based carrier (Hendriksen, Puder, \& Olsen, 2014). To quantify the effect of asparaginase in food applications, its activity needs to be with the concomitant loss of absorbance measured at $340 \mathrm{~nm}$. The asparaginase activity is

\subsection{Asparaginase activity under different conditions} determined. For the two commercially available enzymes (Acrylaway® by Novozymes and PreventASe ${ }^{\mathrm{TM}}$ by DSM), two different methods to determine the activity of the enzyme have been used. Both methods are based on measuring the ammonia that is generated from the asparagine hydrolysis. However, in the method used to measure the activity of Acrylaway, ammonia subsequently reacts with $\alpha$-ketoglutarate to form L-glutamic acid. The reaction is catalysed by glutamate dehydrogenase in the presence of $\mathrm{NADH}$, which is oxidised to NAD+ measured as the rate of NADH consumption under standard conditions $\left(\mathrm{pH}=7 ; 37^{\circ} \mathrm{C}\right)$. The 
activity of asparaginase is expressed in ASNU activity units. One ASNU is defined as the

411

412 amount of asparaginase that produces one micromole of ammonia per minute under standard conditions (Hendriksen et al., 2009). The activity of PreventASe ${ }^{\mathrm{TM}}$ is measured by a different method. The liberated ammonia subsequently reacts with phenol nitroprusside and alkaline hypochlorite resulting in a blue colour. This is known as the Berthelot reaction (Rhine, Sims, Mulvaney, \& Pratt, 1998). The activity of asparaginase is determined by measuring the absorbance of the reaction mixture at $600 \mathrm{~nm}$. Asparaginase activity is expressed in ASPU activity units. One ASPU is defined as the amount of asparaginase that liberates one micromole of ammonia from L-asparagine per minute under standard conditions $(\mathrm{pH}=5.0$; $\left.37^{\circ} \mathrm{C}\right)$.

By setting up a standard activity determination method, the activity of the enzyme under different conditions of $\mathrm{pH}$ and temperature can be measured. From the work done by Hendriksen's group in Novozymes, it was shown that Acrylaway ${ }^{\circledR}$ has almost two times the activity at $60{ }^{\circ} \mathrm{C}$ compared to its activity at $37^{\circ} \mathrm{C}$. Also, the activity of the enzyme at pH 7 is almost two times its activity at $\mathrm{pH}$. These differences in activity should be considered prior to the application of the enzyme to a substrate.

\subsection{Practicalities of asparaginase application}

The practicalities of asparaginase application can be assessed from three different aspects: raw material composition, processing and commerce.

The amount of asparagine in a foodstuff should be considered when deciding the dosage of asparaginase. For example, concentrations of free asparagine in potato may vary by a factor of 10 or more, and can be affected by variety and growing conditions, (Halford et al., 2012b).

When using asparaginase in food manufacture, factors like temperature, time and substrate 
ratio are of importance. For example, the optimal temperature for Acrylaway® is around 60 ${ }^{\circ} \mathrm{C}$ and its activity will decrease significantly above this temperature (Hendriksen et al., 2009). Hence asparaginase will be denatured and inactivated during food processing. The dwell time for enzyme and foodstuff before heat treatment should be optimised before application. Enzyme-substrate ratio is also an important factor and dosage of the enzyme should be determined, so that maximum mitigation is achieved with minimum enzyme concentration. Extra water may be used to ensure the delivery of the enzyme (Whitehurst \& Van Oort, 2009).

Even though asparaginase has advantages over other mitigation methods, its use by manufacturers may not be commercially viable at present. There are also issues with the industrial application of asparaginase in a continuous process, which can achieve good results in a relatively short time. Pilot-scale experiments have been carried out using a continuous process for French fries production (Hendriksen et al., 2009). High levels of acrylamide reduction were achieved (60-85\% in French Fries and 60\% in potato chips). However, more research is needed to better incorporate asparaginase usage into industrial-scale food production. To maximise the overall effect of the enzymatic method, pre- and post-treatment procedures may need to be adapted; for instance, reduction of starting material dimensions and blanching before enzyme treatment and modification of the process conditions after the enzyme treatment by, for example, changing cooking temperature and $\mathrm{pH}$.

\section{Conclusions}

Asparaginase has become a powerful tool for acrylamide mitigation in the food industry. With the success of commercial products, it is likely that asparaginase will be used more and more. The first commercially available "acrylamide-free" product, biscuits treated with 
458 Preventase ${ }^{\mathrm{TM}}$, was announced to launch shortly in Germany for Christmas, 2008. This 459 information was released by DSM Food Specialities, although the manufacturer's name was 460 not disclosed (Foodingredients1st, 2008). However, there was no more news subsequently.

461 The potential adverse effects of asparaginase treatment on sensory properties of cooked 462 foods and the need to achieve sufficient enzyme-substrate contact are areas for future 463 research. However, if the application of asparaginase becomes commercially attractive, its 464 use alongside raw materials low in asparagine may provide the solution to the acrylamide 465 problem. 
Amrein, T. M., Schönbächler, B., Escher, F., \& Amadò, R. (2004). Acrylamide in gingerbread: Critical factors for formation and possible ways for reduction. Journal of Agricultural and Food Chemistry, 52(13), 4282-4288.

Anese, M., Quarta, B., \& Frias, J. (2011a). Modelling the effect of asparaginase in reducing acrylamide formation in biscuits. Food Chemistry, 126(2), 435-440.

Anese, M., Quarta, B., Peloux, L., \& Calligaris, S. (2011b). Effect of formulation on the capacity of 1-asparaginase to minimize acrylamide formation in short dough biscuits. Food Research International, 44(9), 2837-2842.

Banchero, M., Pellegrino, G., \& Manna, L. (2013). Supercritical fluid extraction as a potential mitigation strategy for the reduction of acrylamide level in coffee. Journal of Food Engineering, 115(3), 292-297.

Bartkiene, E., Jakobsone, I., Juodeikiene, G., Vidmantiene, D., Pugajeva, I., \& Bartkevics, V. (2013a). Effect of lactic acid fermentation of lupine wholemeal on acrylamide content and quality characteristics of wheat-lupine bread. International Journal of Food Sciences and Nutrition, 64(7), 890-896.

Bartkiene, E., Jakobsone, I., Juodeikiene, G., Vidmantiene, D., Pugajeva, I., \& Bartkevics, V. (2013b). Study on the reduction of acrylamide in mixed rye bread by fermentation with bacteriocin-like inhibitory substances producing lactic acid bacteria in combination with Aspergillus niger glucoamylase. Food Control, 30(1), 35-40.

Becalski, A., Lau, B. P. Y., Lewis, D., \& Seaman, S. W. (2002). Acrylamide in Foods: Occurrence, Sources, and Modeling. Journal of Agricultural and Food Chemistry, $51(3), 802-808$.

Bråthen, E., \& Knutsen, S. H. (2005). Effect of temperature and time on the formation of acrylamide in starch-based and cereal model systems, flat breads and bread. Food 
493

494

495

496

497

498

499

500

501

502

503

504

505

506

507

508

509

510

511

512

513

514

515

516

Bushman, J. E., Palmieri, D., Whinna, H. C., \& Church, F. C. (2000). Insight into the mechanism of asparaginase-induced depletion of antithrombin III in treatment of childhood acute lymphoblastic leukemia. Leukemia Research, 24(7), 559-565.

Ciesarová, Z., Kiss, E., \& Boegl, P. (2006). Impact of L-asparaginase on acrylamide content in potato products. Journal of Food and Nutrition Research, 45(4), 141-146.

Ciesarová, Z., Kukurová, K., Mikušová, L., Basil, E., Polakovičová, P., Duchoňová, L., Vlček, M., \& Šturdík, E. (2014). Nutritionally enhanced wheat-oat bread with reduced acrylamide level. Quality Assurance and Safety of Crops \& Foods, 6(3), 327-334.

Claus, A., Mongili, M., Weisz, G., Schieber, A., \& Carle, R. (2008). Impact of formulation and technological factors on the acrylamide content of wheat bread and bread rolls. Journal of Cereal Science, 47(3), 546-554.

Curtis, T. Y., Powers, S. J., Balagiannis, D., Elmore, J. S., Mottram, D. S., Parry, M. A. J., Rakszegi, M., Bedö, Z., Shewry, P. R., \& Halford, N. G. (2010). Free amino acids and sugars in rye grain: Implications for acrylamide formation. Journal of Agricultural and Food Chemistry, 58, 1959-1969.

Elmore, J. S., Briddon, A., Dodson, A. T., Muttucumaru, N., Halford, N. G., \& Mottram, D. S. (2015). Acrylamide in potato crisps prepared from 20 UK-grown varieties: Effects of variety and tuber storage time. Food Chemistry, 182, 1-8.

Elmore, J. S., Mottram, D. S., Muttucumaru, N., Dodson, A. T., Parry, M. A. J., \& Halford, N. G. (2007). Changes in free amino acids and sugars in potatoes due to sulfate fertilization and the effect on acrylamide formation. Journal of Agricultural and Food Chemistry, 55(13), 5363-5366.

Foodingredients1st. (2008). First "Acrylamide-Free" Biscuits Will be Launched in Germany. In).http://www.foodingredientsfirst.com/search-results/First-Acrylamide-Free- 
Friedman, M. (2003). Chemistry, biochemistry, and safety of acrylamide. A review. Journal of Agricultural and Food Chemistry, 51(16), 4504-4526.

Friedman, M. (2015). Acrylamide: inhibition of formation in processed food and mitigation of toxicity in cells, animals, and humans. Food \& Function, 6(6), 1752-1772.

Gama-Baumgartner, F., Grob, K., \& Biedermann, M. (2004). Citric acid to reduce acrylamide formation in French fries and roasted potatoes. Mitteilungen aus Lebensmitteluntersuchung und Hygiene, 95(1), 110-117.

Gökmen, V., \& Șenyuva, H. Z. (2007). Acrylamide formation is prevented by divalent cations during the Maillard reaction. Food Chemistry, 103(1), 196-203.

Granvogl, M., \& Schieberle, P. (2006). Thermally generated 3-aminopropionamide as a transient intermediate in the formation of acrylamide. Journal of Agricultural and Food Chemistry, 54(16), 5933-5938.

Halford, N. G., Curtis, T. Y., Muttucumaru, N., Postles, J., Elmore, J. S., \& Mottram, D. S. (2012a). The acrylamide problem: a plant and agronomic science issue. Journal of Experimental Botany, 63(8), 2841-2851.

Halford, N. G., Muttucumaru, N., Powers, S. J., Gillatt, P. N., Hartley, L., Elmore, J. S., \& Mottram, D. S. (2012b). Concentrations of free amino acids and sugars in nine potato varieties: effects of storage and relationship with acrylamide formation. Journal of Agricultural and Food Chemistry, 60(48), 12044-12055.

Hamzalioğlu, A., \& Gökmen, V. (2012). Role of bioactive carbonyl compounds on the conversion of asparagine into acrylamide during heating. European Food Research and Technology, 235(6), 1093-1099.

Hedegaard, R. V., Frandsen, H., \& Skibsted, L. H. (2008). Kinetics of formation of acrylamide and Schiff base intermediates from asparagine and glucose. Food 
Hendriksen, H. V., Kornbrust, B. A., Ostergaard, P. R., \& Stringer, M. A. (2009). Evaluating the potential for enzymatic acrylamide mitigation in a range of food products using an asparaginase from Aspergillus oryzae. Journal of Agricultural and Food Chemistry, 57(10), 4168-4176.

Hendriksen, H. V., Budolfsen, G., \& Baumann, M. J. (2013). Asparaginase for acrylamide mitigation in food. Aspects of Applied Biology, 116, 41-50.

Hendriksen, H. V.; Puder, K.; Olsen, A. G. Method for reducing the level of asparagine in a food material. International Patent No. WO/2014/161935, October $9^{\text {th }}, 2014$.

\section{http://www.novozymes.com/en/news/news-archive/Pages/New-Novozymes'-solution-} enables-acrylamide-mitigation-in-even-more-product-categories--.aspx. Accessed $6^{\text {th }}$ April, 2016.

Huang, L., Liu, Y., Sun, Y., Yan, Q., \& Jiang, Z. (2014). Biochemical characterization of a novel L-asparaginase with low glutaminase activity from Rhizomucor miehei and Its application in food safety and leukemia treatment. Applied and Environmental Microbiology, 80(5), 1561-1569.

JECFA (2007). Compendium of Food Additive Specifications. Monograph No. 4. Rome: FAO.

Jin, C., Wu, X., \& Zhang, Y. (2013). Relationship between antioxidants and acrylamide formation: A review. Food Research International, 51(2), 611-620.

Kamkar, A., Qajarbeygi, P., Jannat, B., Babaei, A. H. H., Misaghi, A., \& Aghaee, E. M. (2015). The inhibitory role of autolysed yeast of Saccharomyces cerevisiae, vitamins B-3 and B-6 on acrylamide formation in potato chips. Toxin Reviews, 34(1), 1-5.

Kenari, S. L. D., Alemzadeh, I., \& Maghsodi, V. (2011). Production of L-asparaginase from Escherichia coli ATCC 11303: Optimization by response surface methodology. Food 
Krasotkina, J., Borisova, A. A., Gervaziev, Y. V., \& Sokolov, N. N. (2004). One-step purification and kinetic properties of the recombinant L-asparaginase from Erwinia carotovora. Biotechnology and Applied Biochemistry, 39, 215-221.

Kukurová, K., Morales, F. J., Bednáriková, A., \& Ciesarová, Z. (2009). Effect of Lasparaginase on acrylamide mitigation in a fried-dough pastry model. Molecular Nutrition \& Food Research, 53(12), 1532-1539.

Kukurová, K., Ciesarová, Z., Mogol, B. A., Açar, O. C., \& Gökmen, V. (2013). Raising agents strongly influence acrylamide and HMF formation in cookies and conditions for asparaginase activity in dough. European Food Research and Technology, 237(1), $1-8$.

Kumar, N. S. M., Shimray, C. A., Indrani, D., \& Manonmani, H. K. (2014). Reduction of acrylamide formation in sweet bread with L-asparaginase treatment. Food and Bioprocess Technology, 7(3), 741-748.

Kundu, B.; Bansal, S.; Mishra, P. Mutants of L-asparaginase. US Patent No.20130330316, $12^{\text {th }}$ December, 2013.

Lisińska, G., Tajner-Czopek, A., \& Kalum, L. (2007). The effects of enzymes on fat content and texture of French fries. Food Chemistry, 102(4), 1055-1060.

Liu, J., Man, Y., Zhu, Y., Hu, X., \& Chen, F. (2013). Simultaneous analysis of acrylamide and its key precursors, intermediates, and products in model systems by liquid chromatography-triple quadrupole mass spectrometry. Analytical Chemistry, 85(19), $9262-9271$.

Low, M. Y., Parker, J. K., \& Mottram, D. S. (2007). Mechanisms of alkylpyrazine formation in a potato model system containing added glycine. Journal of Agricultural and Food Chemistry, 55(10), 4087-4094. 
Mahajan, R. V., Saran, S., Kameswaran, K., Kumar, V., \& Saxena, R. K. (2012). Efficient production of L-asparaginase from Bacillus licheniformis with low-glutaminase activity: optimization, scale up and acrylamide degradation studies. Bioresource Technology, 125, 11-16.

Masi, C., Dinnella, C., Barnaba, M., Navarini, L., \& Monteleone, E. (2013). Sensory properties of under-roasted coffee beverages. Journal of Food Science, 78(8), S12901300.

Mottram, D. S., Wedzicha, B. L., \& Dodson, A. T. (2002). Acrylamide is formed in the Maillard reaction. Nature, 419(6906), 448-449.

Muttucumaru, N., Halford, N. G., Elmore, J. S., Dodson, A. T., Parry, M., Shewry, P. R., \& Mottram, D. S. (2006). Formation of high levels of acrylamide during the processing of flour derived from sulfate-deprived wheat. Journal of Agricultural and Food Chemistry, 54(23), 8951-8955.

Muttucumaru, N., Powers, S. J., Elmore, J. S., Mottram, D. S., \& Halford, N. G. (2013). Effects of nitrogen and sulfur fertilization on free amino acids, sugars, and acrylamide-forming potential in potato. Journal of Agricultural and Food Chemistry, 61(27), 6734-6742.

Ohara-Takada, A., Matsuura-Endo, C., Chuda, Y., Ono, H., Yada, H., Yoshida, M., Kobayashi, A., Tsuda, S., Takigawa, S., Noda, T., Yamauchi, H., \& Mori, M. (2005). Change in content of sugars and free amino acids in potato tubers under short-term storage at low temperature and the effect on acrylamide level after frying. Bioscience, Biotechnology and Biochemistry, 69(7), 1232-1238.

Onishi, Y., Prihanto, A. A., Yano, S., Takagi, K., Umekawa, M., \& Wakayama, M. (2015). Effective treatment for suppression of acrylamide formation in fried potato chips using L-asparaginase from Bacillus subtilis. 3 Biotech, 5(5), 783-789. 
Palazoğlu, T. K., \& Gökmen, V. (2008). Reduction of acrylamide level in French fries by employing a temperature program during frying. Journal of Agricultural and Food Chemistry, 56(15), 6162-6166.

Parker, J. K., Balagiannis, D. P., Higley, J., Smith, G., Wedzicha, B. L., \& Mottram, D. S. (2012). Kinetic model for the formation of acrylamide during the finish-frying of commercial French fries. Journal of Agricultural and Food Chemistry, 60(36), 93219331.

Pedreschi, F., Kaack, K., \& Granby, K. (2008). The effect of asparaginase on acrylamide formation in French fries. Food Chemistry, 109(2), 386-392.

Pedreschi, F., Mariotti, M. S., \& Granby, K. (2014). Current issues in dietary acrylamide: formation, mitigation and risk assessment. Journal of the Science of Food and Agriculture, 94(1), 9-20.

Pedreschi, F., Mariotti, S., Granby, K., \& Risum, J. (2011). Acrylamide reduction in potato chips by using commercial asparaginase in combination with conventional blanching. LWT-Food Science and Technology, 44(6), 1473-1476.

Pritsa, A. A., \& Kyriakidis, D. A. (2001). L-Asparaginase of Thermus thermophilus: Purification, properties and identification of essential amino acids for its catalytic activity. Molecular and Cellular Biochemistry, 216(1-2), 93-101.

Qin, M., \& Zhao, F. S. (2003). L-asparaginase release from Escherichia coli cells with aqueous two-phase micellar systems. Applied Biochemistry and Biotechnology, $110(1), 11-21$.

Rak, K., Navarro, F. M., \& Palta, J. P. (2013). Genotype x storage environment interaction and stability of potato chip color: Implications in breeding for cold storage chip quality. Crop Science, 53(5), 1944-1952.

Rhine, E. D., Sims, G. K., Mulvaney, R. L., \& Pratt, E. J. (1998). Improving the Berthelot 
reaction for determining ammonium in soil extracts and water. Soil Science Society of America Journal, 62(2), 473-480.

Roberts, J., Holcenberg, J. S., \& Dolowy, W. C. (1972). Isolation, crystallization, and properties of Achromobacteraceae glutaminase-asparaginase with antitumor activity. Journal of Biological Chemistry, 247(1), 84-90.

Rydberg, P., Eriksson, S., Tareke, E., Karlsson, P., Ehrenberg, L., \& Tornqvist, M. (2003). Investigations of factors that influence the acrylamide content of heated foodstuffs. Journal of Agricultural and Food Chemistry, 51(24), 7012-7018.

Sadd, P. A., Hamlet, C. G., \& Liang, L. (2008). Effectiveness of methods for reducing acrylamide in bakery products. Journal of Agricultural and Food Chemistry, 56(15), 6154-6161.

Salazar, R., Arambula-Villa, G., Luna-Barcenas, G., Figueroa-Cardenas, J. D., Azuara, E., \& Vazquez-Landaverde, P. A. (2014). Effect of added calcium hydroxide during corn nixtamalization on acrylamide content in tortilla chips. LWT-Food Science and Technology, 56(1), 87-92.

Sansano, M., Juan-Borras, M., Escriche, I., Andres, A., \& Heredia, A. (2015). Effect of pretreatments and air-frying, a novel technology, on acrylamide generation in fried potatoes. Journal of Food Science, 80(5), T1120-T1128.

Shu, C.-K. (1999). Pyrazine formation from serine and threonine. Journal of Agricultural and Food Chemistry, 47, 4332-4335.

Sieciechowicz, K. A., Joy, K. W., \& Ireland, R. J. (1988). The metabolism of asparagine in plants. Phytochemistry, 27(3), 663-671.

Spiller, G. A. (1997). Caffeine: London: Taylor \& Francis.

Stadler, R. H., Blank, I., Varga, N., Robert, F., Hau, J., Guy, P. A., Robert, M.-C., \& Riediker, S. (2002). Acrylamide from Maillard reaction products. Nature, 419, 449-450. 
Tareke, E. (2003). Identification and Origin of Potential Background Carcinogens: Endogenous Isoprene and Oxiranes, Dietary Acrylamide. Ph.D. thesis, Department of Environmental Chemistry, University of Stockholm.

Tareke, E., Rydberg, P., Karlsson, P., Eriksson, S., \& Tornqvist, M. (2002). Analysis of acrylamide, a carcinogen formed in heated foodstuffs. Journal of Agricultural and Food Chemistry, 50(17), 4998-5006.

Tuncel, N. B., Y1lmaz, N., \& Șener , E. (2010). The effect of pea (Pisum sativum L.)originated asparaginase on acrylamide formation in certain bread types. International Journal of Food Science and Technology, 45(12), 2470-2476.

Vinci, R. M., Mestdagh, F., \& De Meulenaer, B. (2012). Acrylamide formation in fried potato products - present and future, a critical review on mitigation strategies. Food Chemistry, 133(4), 1138-1154.

Whitehurst, R. J., \& Van Oort, M. (2009). Enzymes in Food Technology: Oxford, UK: WileyBlackwell

Wriston, J. C. (1985). Asparaginase. Methods in Enzymology, 113, 608-618.

Xu, F.; Khalid, P.; Oruna-Concha, M.-J.; Elmore, J. S. (2015). Effect of asparaginase on flavour formation in roasted coffee. In: A.J. Taylor, \& D. S. Mottram (Eds.), Flavour Science (563-566). Packington, United Kingdom: Context Products Ltd.

Yao, M., Yasutake, Y., Morita, H., \& Tanaka, I. (2005). Structure of the type I L-asparaginase from the hyperthermophilic archaeon Pyrococcus horikoshii at 2.16 angstrom resolution. Acta Crystallographica Section D-Biological Crystallography, 61, 294301.

Zamora, R., Delgado, R. M., \& Hidalgo, F. J. (2011). Strecker aldehydes and alpha-keto acids, produced by carbonyl-amine reactions, contribute to the formation of acrylamide. Food Chemistry, 128(2), 465-470. 
Zamora, R., \& Hidalgo, F. J. (2008). Contribution of lipid oxidation products to acrylamide formation in model systems. Journal of Agricultural and Food Chemistry, 56(15), 6075-6080.

Zuo, S., Zhang, T., Jiang, B., \& Mu, W. (2015a). Recent research progress on microbial Lasparaginases. Applied Microbiology and Biotechnology, 99, 1069-1079.

Zuo, S., Zhang, T., Jiang, B., \& Mu, W. (2015b). Reduction of acrylamide level through blanching with treatment by an extremely thermostable L-asparaginase during French fries processing. Extremophiles, 19(4), 841-851.

Zyzak, D. V., Sanders, R. A., Stojanovic, M., Tallmadge, D. H., Eberhart, B. L., Ewald, D. K., Gruber, D. C., Morsch, T. R., Strothers, M. A., Rizzi, G., \& Villagran, M. D. (2003). Acrylamide formation mechanisms in heated foods. Journal of Agricultural and Food Chemistry, 51(4782-4787).

Zyzak, D. V., Sanders, R. A., Stojanovic, M., Tallmadge, D. H., Eberhart, B. L., Ewald, D. K., Gruber, D. C., Morsch, T. R., Strothers, M. A., Rizzi, G. P., \& Villagran, M. D. (2003). Acrylamide formation mechanism in heated foods. Journal of Agricultural and Food Chemistry, 51(16), 4782-4787. 


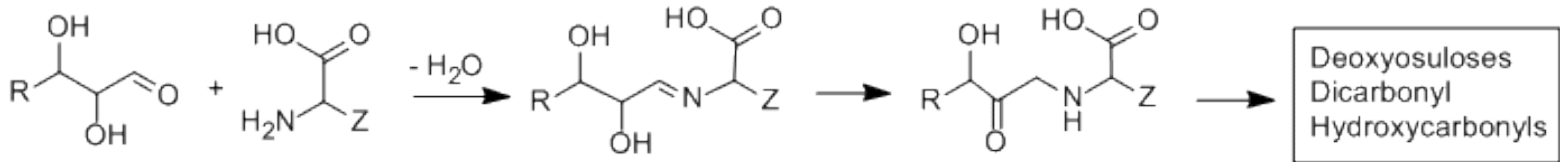

$$
\text { reducing sugar } \quad \alpha \text {-amino acid Schiff base }
$$

Amadori compound

Generic amino acid pathway
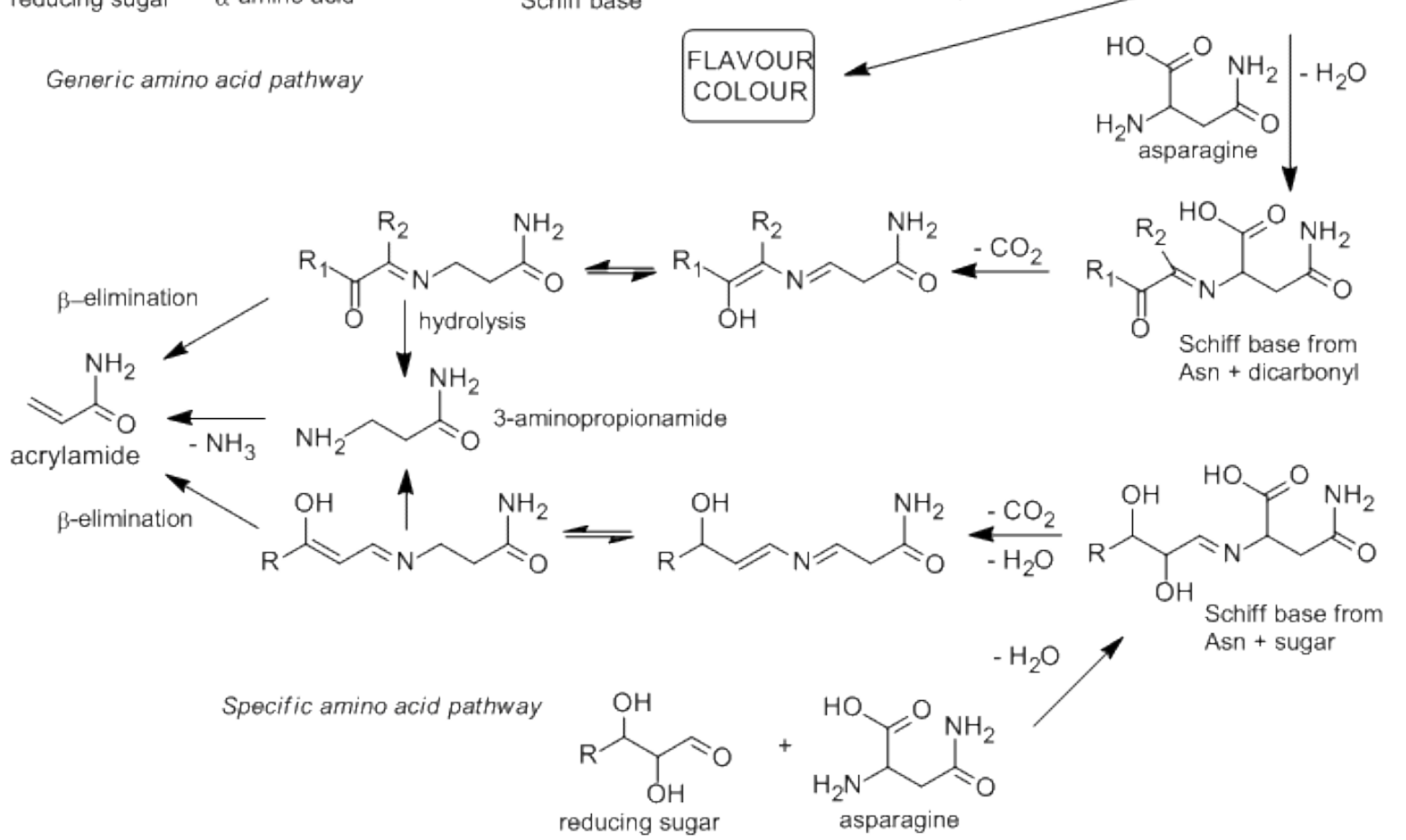

$260{ }^{\circ} \mathrm{C}$ for $5.5 \mathrm{~min}$. (b) Effect of asparaginase (Acrylaway®; 2100 ASNU/kg of flour) incubation conditions on acrylamide formation in crispbread; crispbread was baked at $250^{\circ} \mathrm{C}$ for $11 \mathrm{~min}$ (adapted from Hendriksen, Kornbrust, Ostergaard, and Stringer (2009)).

719
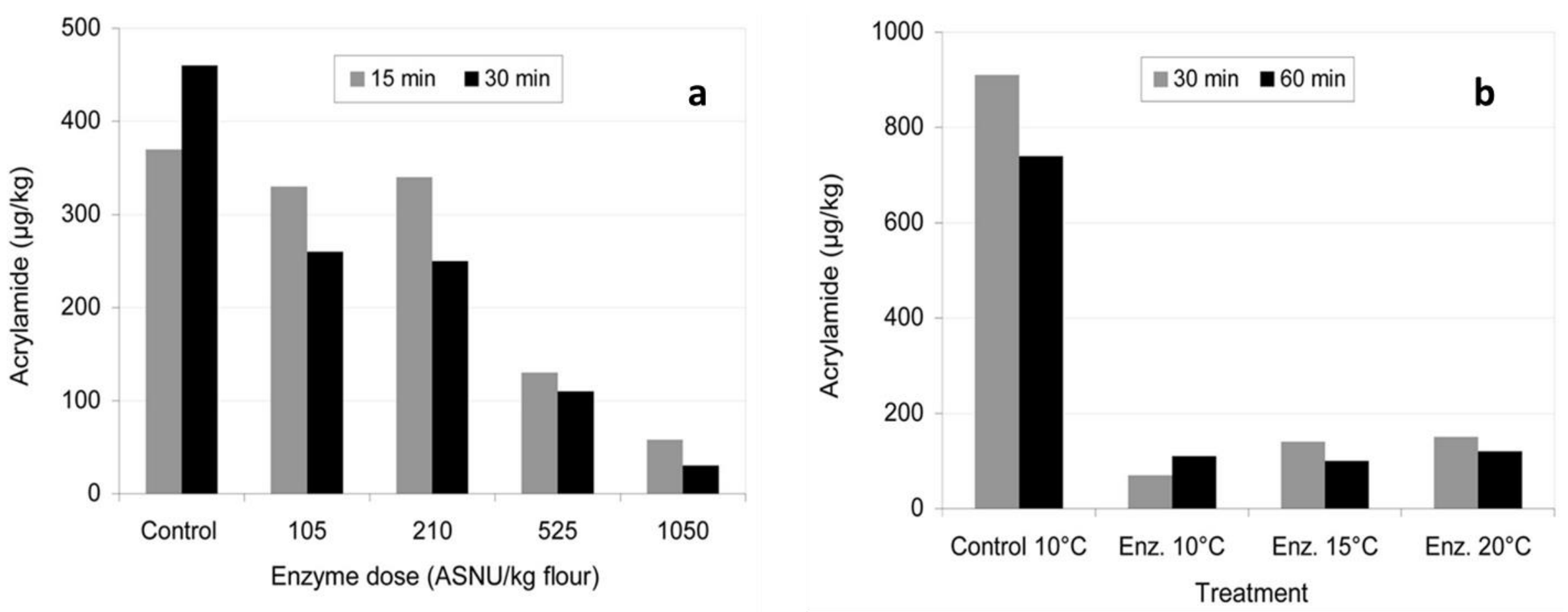
Table 1 Results published on enzymatic mitigation of acrylamide using asparaginase

\begin{tabular}{|c|c|c|c|c|c|}
\hline foodstuff & enzyme source & enzyme dosage & processing conditions & acrylamide reduction & reference \\
\hline potato & Escherichia coli & not stated & not stated & $99 \%$ & Zyzak et al. (2003) \\
\hline gingerbread & E. coli & $4 \mathrm{U} / \mathrm{kg}$ & $\begin{array}{l}\text { various time/temperature } \\
\text { combinations }\end{array}$ & $55 \%$ & Amrein et al.(2004) \\
\hline potato & E. coli & $0.2-1 \mathrm{U} / \mathrm{g}$ & $180^{\circ} \mathrm{C}, 20 \mathrm{~min}$ & $50-90 \%$ & Ciesarová et al. (2006) \\
\hline French fries & A. oryzae & $10000 \mathrm{ASNU} / \mathrm{L}^{*}$ & $175^{\circ} \mathrm{C}, 3 \mathrm{~min}$ & $67 \%$ & Pedreschi et al. (2008) \\
\hline $\begin{array}{l}\text { semi-sweet biscuits, ginger } \\
\text { biscuits, crispbread, French } \\
\text { fries, potato crisps }\end{array}$ & A. oryzae & various dosages & $\begin{array}{l}\text { various time/temperature } \\
\text { combinations }\end{array}$ & $\begin{array}{l}\text { semi-sweet biscuits: } 65-84 \% \\
\text { ginger biscuits: } 34-90 \% \\
\text { crispbread: } 84-92 \% \\
\text { French fries: } 59 \% \\
\text { potato crisps: } 60 \%\end{array}$ & Hendriksen et al. (2009) \\
\hline fried dough model system & A. oryzae & $100,500,1000 \mathrm{U} / \mathrm{kg}$ & 180 or $200^{\circ} \mathrm{C} ; 4,6$ or $8 \mathrm{~min}$ & $90 \%$ & Kukurová et al. (2009) \\
\hline bread & $\begin{array}{l}\text { enzymes from Pisum } \\
\text { sativum L. }\end{array}$ & not stated & $220^{\circ} \mathrm{C}, 22-25 \mathrm{~min}$ & $\begin{array}{l}\text { wheat bran bread: } 57 \% \\
\text { whole-grain bread: } 68 \%\end{array}$ & Tuncel et al. (2010) \\
\hline potato chips & A. oryzae & $10000 \mathrm{ASNU} / \mathrm{L}$ & $170^{\circ} \mathrm{C}, 5 \mathrm{~min}$ & $90 \%$ & Pedreschi et al. (2011) \\
\hline biscuits & A. oryzae & $100-900 \mathrm{U} / \mathrm{kg}$ & $\begin{array}{l}200{ }^{\circ} \mathrm{C} \text {, final moisture content } \\
2 \%\end{array}$ & $7-88 \%$ & Anese et al. (2011a) \\
\hline biscuits & A. oryzae & $900 \mathrm{U} / \mathrm{kg}$ & $\begin{array}{l}200{ }^{\circ} \mathrm{C} \text {, final moisture content } \\
2 \%\end{array}$ & $69 \%$ & Anese et al. (2011b) \\
\hline potato & Bacillus licheniformis & $30 \mathrm{IU} / \mathrm{mL}$ & $175^{\circ} \mathrm{C}, 15 \mathrm{~min}$ & $80 \%$ & Mahajan et al. (2012) \\
\hline $\begin{array}{l}\text { lebkuchen, tortilla chips, potato } \\
\text { snack, French fries, coffee }\end{array}$ & A. oryzae & various dosages & $\begin{array}{l}\text { lebkuchen: } 200^{\circ} \mathrm{C}, 14 \mathrm{~min} \\
\text { tortilla chips: } 190^{\circ} \mathrm{C}, 60 \mathrm{~s}\end{array}$ & $\begin{array}{l}\text { lebkuchen: } 95 \% \\
\text { tortilla chips: } 90 \%\end{array}$ & $\begin{array}{l}\text { Hendriksen et al. } \\
\text { (2013). }\end{array}$ \\
\hline
\end{tabular}




\begin{tabular}{|c|c|c|c|c|c|}
\hline & & & $\begin{array}{l}\text { French fries: } 175^{\circ} \mathrm{C}, 3 \mathrm{~min} \\
\text { others not specified }\end{array}$ & $\begin{array}{l}\text { potato snack: } 40 \% \\
\text { French fries: } 57 \% \\
\text { coffee: } 55-74 \%\end{array}$ & \\
\hline cookies & A. oryzae & $500 \mathrm{U} / \mathrm{kg}$ & $205^{\circ} \mathrm{C}, 11$ or $15 \mathrm{~min}$ & $23-75 \%$ & Kukurová et al. (2013) \\
\hline wheat-oat bread & Aspergillus niger & $500 \mathrm{U}$ & $\begin{array}{l}220,230 \text { and } 250{ }^{\circ} \mathrm{C} ; 10,30 \text { and } \\
40 \mathrm{~min}\end{array}$ & $90 \%$ & Ciesarová et al. (2014) \\
\hline sweet bread & Cladosporium sp. & $50-300 \mathrm{U}$ & $220^{\circ} \mathrm{C} ; 25 \mathrm{~min}$ & $\begin{array}{l}\text { sweet bread crust: } 97 \% \\
\text { sweet bread crumb: } 73 \%\end{array}$ & Kumar et al. (2014) \\
\hline biscuits, bread & Rhizomucor miehei & $0.5-10 \mathrm{U}$ & $200{ }^{\circ} \mathrm{C} ; 15 \mathrm{~min}$ & $\begin{array}{l}\text { biscuits: } 81.6 \% \\
\text { bread: } 94.2 \%\end{array}$ & Huang et al. (2014) \\
\hline potato crisps & Bacillus subtilis & $0-40 \mathrm{U}$ & $170{ }^{\circ} \mathrm{C} ; 90 \mathrm{~s}$ & $80 \%$ & Onishi et al. (2015) \\
\hline French fries & Thermococcus zilligii & $0-20 \mathrm{U}$ & $175^{\circ} \mathrm{C} ; 5 \mathrm{~min}$ & $80 \%$ & Zuo et al. (2015b) \\
\hline
\end{tabular}

$*$ ASNU is defined as the amount of asparaginase that produces $1 \mu \mathrm{mol}$ of ammonia per min under the conditions of the assay (pH $=7 \pm 0.005$; $37 \pm 0.5{ }^{\circ} \mathrm{C}$ ) using Acrylaway ${ }^{\circledR}$ 